\title{
Towards a typology of non-state actors in 'hybrid warfare': proxy, auxiliary, surrogate and affiliated forces
}

Article

Accepted Version

Rauta, V. (2020) Towards a typology of non-state actors in 'hybrid warfare': proxy, auxiliary, surrogate and affiliated forces. Cambridge Review of International Affairs, 33 (6). pp. 868-887. ISSN 1474-449X doi:

https://doi.org/10.1080/09557571.2019.1656600 Available at https://centaur.reading.ac.uk/86256/

It is advisable to refer to the publisher's version if you intend to cite from the work. See Guidance on citing.

To link to this article DOI: http://dx.doi.org/10.1080/09557571.2019.1656600

Publisher: Taylor \& Francis

All outputs in CentAUR are protected by Intellectual Property Rights law, including copyright law. Copyright and IPR is retained by the creators or other copyright holders. Terms and conditions for use of this material are defined in the End User Agreement.

www.reading.ac.uk/centaur 
Central Archive at the University of Reading

Reading's research outputs online 


\title{
Towards a Typology of Non-State Actors in 'Hybrid Warfare': Proxy, Auxiliary, Surrogate, and Affiliated Forces
}

\author{
Vladimir Rauta
}

\section{School of Politics, Economics and International Relations, University of Reading v.rauta@reading.ac.uk}

\begin{abstract}
This article presents a typology of armed non-state actors that shape the military dimension of bybrid warfare: proxy, auxiliary, surrogate, and affiliated forces. By focusing on the kinetic domain of bybrid warfare, the article offers a corrective to a debate which has so far ignored variation in roles and functions of non-state actors and their relationships with internal and external states and their regular forces. As a denominator, 'bybrid' identifies a combination of battlespaces, types of operations - military or non-kinetic - and a blurring of actors with the scope of achieving strategic objectives by creating exploitable ambiguity. However, there has been a disproportionate focus on what hybrid war supposedly combines across battlespaces and domains (socio-political, economic, informational), at the expense of who and how this combination takes place. Using the Ukrainian crisis as a theory-building exercise, the article suggests a four-category schema that identifies non-state actor functions as a tool to better represent the complex franchise of violence that is found nested next to non-military operations in bybrid activity. In so doing, the article speaks to a call for better conceptualisation the role of non-state violent actors in civil war, in general, and in bybrid warfare, in particular.
\end{abstract}

Keywords: proxies, auxiliaries, surrogates, hybrid warfare, civil war, proxy war

\section{Introduction}

In a recent article, Rory Cormac and Richard Aldrich remarked that 'anxiety about ambiguous warfare and hybridity is all the rage' $(2018,477)$. Taking the pulse of the debate on the hybridity of war and warfare, one can clearly see why: a concept that has been refuted by scholarly debate, yet embraced by policymakers and practitioners (Renz 2016; Renz and Smith 2016a; 2016b); an ever-expanding terminological roster (Seely 2017); a rush for policy recommendations that has taken by surprise dormant NATO doctrines (Seely 2017; Oren 2016); and a reality of future warfare whether acknowledged as 'hybrid' or not (Freedman 2017).

The academic debate has reached a consensus that the notion of 'hybrid war/warfare' has to be approached cautiously. From outright rejection (Renz and Smith 2016a; 2016b; Charap 2015; Glenn 2009), to attempts at intellectually disentangling it from a supposed Russian way of war (Galeotti 2019, 2018a; Fridman 2018, 2017; Bartles 2016; Monaghan 2016; Thomas 2016; Thornton 2015), and to milder objections and acceptance (Almäng 2019; Caliskan 2019; Mälksoo 2018; Jacob and Lasconjarias 2015; Schroefl and Kaufman 2014), we now know that hybrid war/warfare' is a conceptual trap. There is a high probability that no other concept in the semantic field of political violence today has had its intellectual credibility challenged in the way 'hybrid war/warfare' has - and rightly so. There is also little comparative evidence that other concepts reached the speed at which policymakers embraced and embedded 'hybrid war' into policy shortly 
after the Russian annexation of the Crimean Peninsula in March 2014. As Samuel Charap noted, its prominence 'surpassed all previous usage' (2015, 51; Fridman 2018; Monaghan 2016; Renz 2016) ${ }^{1}$.

This article locates a problem in our understanding of the phenomenon, and one that has serious implications given the policy traction hybrid warfare has developed. It concerns the issue of armed non-state actors in the military domain of hybrid war/warfare and the roles they carry out in collaboration with, for, or alongside internal and external, official or semi-official forces. The following is a standard definition of 'hybrid warfare':

'The idea of hybrid warfare [...] is seen, in essence, as a form of warfare characterised by 'blurring'. At its most basic level, the aim is to generate a situation where it is unclear whether a state of war exists - and if it does, who is a combatant and who is not' (emphasis added, Thornton 2015, 41).

We know that as a denominator, 'hybrid' identifies a combination of battlespaces, types of operations - military or non-kinetic -, and a blurring of actors with the scope of achieving strategic objectives by creating 'exploitable ambiguity' (Cormac and Aldrich 2018, 490). Herein lies the problem this article tackles: there has been a disproportionate focus on what bybrid war supposedly combines across battlespaces, at the expense of who is combined and how this combination takes place. Simply put, we know that hybrid war has the capacity of combing armed action across all five domains of space, cyber, maritime, air, and land within wider campaigns involving politico-economic, socio-cultural, and informational dimensions (Lanoszka 2019, 2016). Yet, we know very little about the types, roles, and relationships involving actors both within and across these layers, outside claims about their regular-irregular nature and the synergy of their actions (Hoffman 2007).

The article focuses on the 'warfare' layer of activity, no doubt the most problematic element of hybrid activity (Wigell 2019, 260). It understands 'warfare' in a very narrow sense as including military means amounting to armed interaction (Wigell 2019, 261), and in so doing it follows a turn in the literature towards disaggregating the layers, types, or dimensions of hybrid activity (Lanoszka 2019, Wigell 2019, Mälksoo 2018). The article's aim is to better integrate explanations around the increasing range of armed non-state actors by focusing on their kinetic roles and relationships to other actors or parties in conflict. Specifically, it focuses their strategic roles vis-à-vis parties, regular and irregular, external and internal to the conflict waged under the

\footnotetext{
1 The same can be said for 'asymmetric war/warfare' in the aftermath of $9 / 11$, and, more recently, about 'cyber war/warfare'. I thank the reviewers for pointing this out.
} 
'hybrid' label. It suggests a four-category schema that identifies non-state actor functions as a tool to better represent the complex franchise of violence that is found nested next to non-military operations. The article delineates between four strategic roles: proxy, surrogate, auxiliary, and affiliated.

In so doing, the article speaks to a call for better conceptualisation of the role of violent non-state actors as one part of the wider and full-spectrum (economic, socio-political, informational) coercive efforts captured by hybrid campaigns. Recently, Robert Johnson criticised the hybrid debate for failing to grasp the nature of actors $(2018,147)$, and this article addresses this very issue by presenting a typology as an opportunity to minimise misconception and maximise theoretical progress. The article proceeds as follows. First, it locates the puzzle of the article in the current debate. Second, it introduces a four-category schema addressing the puzzle's theoretical and empirical baseline. Third, it explores variation across the classification by referring to the Ukrainian crisis. The case study choice is informed by the article's attempt at theory-building through typological developments (George and Bennett 2005, 238). The 'little green men', the separatist forces in the south east of Ukraine, the crowdfunding of Ukrainian volunteer battalions fighting to quash shadowy operations by Russian forces, private military contractors, and mercenaries, all obfuscated analytical categories as well as our ability to map their in situ relationships (Bowen 2019; Spearin 2018; Galeotti 2016; Malyarenko and Galbreath 2016; Rauta 2016). Given this variation, a typology becomes an apt tool of management of phenomena complexity, working best in within case study scenarios (Gerring 2004, 92). Finally, the article concludes with a note on the importance of the discussion to scholarly and policy debates alike, and reviews some of the article's limitations by outlining a path for further research.

The Actor Problem in Hybrid Warfare Research

The seizure of three small Ukrainian vessels and twenty-three sailors in the Kerch Strait linking the Sea of Azov to the Black Sea in November 2018, was the first overt armed conflict between Ukraine and Russia since the annexation of Crimea in 2014 (Macfarquhar 2018). Reports immediately described the situation as another phase of the hybrid war Russia has been waging against Ukraine. One such case claimed that the incident added a new maritime dimension to Russia's hybrid approach (Hall 2018), and the European Parliamentary Research Service was quick to locate the tensions in the overall Russian hybrid war effort (Bentzen 2018). Yet, the November skirmishes were different to the combined mode of operations which has led to the characterisation of the annexation of Crimea and the ensuing civil war in the south east of Ukraine 
as shadowy wars (Macfarquhar 2018). NATO’s Secretary General, Jens Stoltenberg, underlined the difference: Russia used military force in an open way (Sengupta 2018). Similarly, the Ukrainian authorities denounced the events as 'a qualitatively different situation, a qualitatively different threat' involving Russian regular forces (Macfarquhar 2018). ${ }^{2}$

The fuzziness over recent events in the percolating war in Ukraine has accompanied this security crisis since its very beginning in late 2013. At the centre of the discussion has been the issue of actorness with its variation, and, more importantly, conceptual and theoretical intractability. At a macro level, this issue taps into the now generally accepted blurring of the warpeace distinction. Prefigured by the debates on the transformations in the character of war (Strachan and Scheipers, 2013), the disappearance of clearly demarcated boundaries between war and peace was thrust into the politico-strategic consciousness by the Russian Chief of the General Staff, Valery Gerasimov, and his now infamous remarks that wars are no longer declared (2013). At a meso level, confusion takes the form of another binary: conventional and non-conventional war. Of course, conventional wars have declined, and civil wars have been on the rise. Most recent data on armed conflict provides evidence that conventional war has virtually disappeared: 'of the 49 conflicts in 2017, only one was fought between states' (Pettersson and Eck 2018, 536). In parallel, the rise in civil wars has led to assessments of the future of war as overwhelmingly irregular (Jones 2018) and predominantly Islamist in character (Walter 2018). Yet, as of 2016, the United States military began relearning how to fight big armies (Cooper 2016). The Trump administration's National Security Strategy has also moved to identify the revisionist powers of China and Russia as challengers (White House 2017). As a consequence, the United States committed roughly 15,000 American troops to NATO's 2018 Trident Juncture exercise in Norway (Cooper 2018), and closely watched Russia's own conventional war games, Vostok, unfold across multiple phases during 2018.

An increased focus on conventional warfare does not, however, simply accompany the future prospects of non-conventional warfare, but is said to be found in a state 'best characterised by convergence' (emphasis in original, Hoffman 2009b, 34). The West, as Seely argued, is still struggling to conceptualise war outside the binary discussed above $(2017,52)$. This is in large part because this dichotomous tendency is reductionist (Gray 2008-2009, 23) and suffering from what Tarak Barkawi called 'Eurocentric limitation' (2016, 200). Against this background, we have seen the rise of the twin notions of 'hybrid war' and 'hybrid warfare' with their multiple synonyms (Seely

\footnotetext{
2 The debate around the hybrid character of the Kerch straight incident requires nuance. As one thoughtful reviewer pointed out, while the incident itself did not amount to hybrid war, the economic context (materialised in prolonged economic pressure campaigns carried out through deniable means) does lead credence to labelling the incident as another facet of the Russian hybrid war against Ukraine.
} 
2017). As early as 2005, James Mattis and Frank Hoffman started speaking of 'hybrid war' as a merger of different modes and means of war. This was later echoed by former U.S. Secretary of Defence, Robert M. Gates, who observed that 'the categories of warfare are blurring and no longer fit into neat, tidy boxes. One can expect to see [...] hybrid and more complex forms of warfare' (2009).

The term 'hybrid' came to encapsulate the melting of war into peace and vice versa, and the combination of modalities of warfare. In a hybrid scenario, competitors combine all forms of war and tactics simultaneously (Hoffman 2009b; Jacobs and Lasconjarias 2015, 2). The essence of the 'hybrid' label was this very issue of combining organisation and means (Hoffman 2007, 28). The emphasis fell on trying to link conventional with non-conventional, criminal with terrorist elements, and to do so across the five domains of battle: air, land, water, cyber, and space. All, of course, placed within a strategic context in which the military competition translates into the socioeconomic, political, and cultural. Definitions from across either side of the debate, academic or policy, emphasised heterogeneity and, in doing so, expanded and contracted based on how wide a research focus they addressed: political warfare, covert and clandestine action ${ }^{3}$, direct and indirect military intervention, subversion, propaganda, disinformation, electoral interference, cyberattacks, energy blackmail, espionage, and organised crime.

By focusing on how and what is combined in 'hybrid war/warfare', however, the debate largely ignored the issues of agency and actorness which this article tackles. As Hoffman makes clear, '[his] own definition [...] focuses on the adversary's modes of conflict' (2009a). The structure of the definition focuses on simultaneity, fusion, and multimodality. The debate acknowledged early on that heterogeneity applied also to actors. General Mark A. Milley, former United States Army Chief of Staff, made the point very clearly: '[future wars] could have conventional forces, Special Forces, guerrillas, terrorists, criminals all mixed together in a highly complex terrain a highly complex terrain with the potentially high densities of civilians' (in Cooper 2016). Hoffman's definition tackled actors inasmuch as they coalesced into 'structures', understood as 'combinations of states, non-state actors, foreign fighters' (2009a).

In one of the very few studies explicitly discussing the question of actors, Josef Schroefl and Stuart Kaufman make two important observations that identify the key puzzle concerning us here. On the one hand, they reiterate hybridity's links to non-state actor variety, 'including any combination of insurgent or terrorist networks; organised crime groups, social groups such as clans, tribes or ethnic groups; and ideologically or religiously motivated organisations' $(2014,867)$.

\footnotetext{
${ }^{3}$ For the purpose of clarity, covert action is understood "as activity to influence events in a plausible deniable manner" (Cormac and Aldrich 2016, 477). Clandestine refers to operations carried in such a way as to assure secrecy or concealment (DeVine and Peters, 2018).
} 
On the other hand, they point to these actors being backed both covertly and overtly, and that these relationships are usually murky $(2014,867)$. The first observation identifies variation of actors: the adversary will be the sum of different actors. The second speaks to the issue of how these actors relate and interact with each other as well as external parties. These observations underline the puzzle the article addresses: in spite of great emphasis on acknowledging an everexpanding range of actors involved in hybrid campaigns, we do not know very clearly how they segment the battlespace through interactions with other state and non-state actors, officially or unofficially involved in the ensuing fighting.

In the next section, the article draws on Schroefl and Kaufman's observations, and interrogates the puzzle of the relational modalities constructing the complex franchise of violence being waged in hybrid war. As explained in the introduction, the focus is on the military dimension of the many layers of hybrid action. Isolating particular domains of hybrid activity is an emerging trend and the debate has improved tremendously by addressing specific issues, such as cyberattacks (Jensen et al 2019), or individual domains: economic (Ratsiborynska 2018), socio-cultural (Robinson et al 2018), and political (Kragh and Asberg 2017). By contracting the scope of the analysis, the article answers a specific call to shift the debate onto the military element of 'warfare' (Monaghan 2016, 66). Given the dearth of research on this issue, a narrow focus allows for a more granular analysis, inviting nevertheless future whole-picture approaches.

\section{A Typology of Actors in 'Hybrid Warfare'}

This section outlines a four-category schema aiming to capture variation across the multiple relationships violent non-state actors develop with regular and irregular actors in hybrid warfare. So far we know that actors can be states and non-state actors. They can find themselves coordinated within/across battlespaces to the extent that they can become blurred into one force (Hoffman 2007, 8). We also know that their fighting is abetted and enabled by other non-state and state actors wishing to change the strategic outcome of the war. Most commonly this has been framed as a proxy relationship. As Lawrence Freedman noted, the role of the separatists in the South-East of Ukraine had some similarities with Hezbollah. Specifically, 'they also had a state sponsor, which ensured that they had resources and modern weaponry, though they were more of a proxy for the Russian interests' (Freedman 2017 224-225). Policymakers agreed. At a 2017 Foreign Ministers meeting at the Organisation for Security and Co-operation in Europe (OSCE), former US Secretary of State, Rex Tillerson, called out Russia's sponsorship of proxies in the 
Ukraine very bluntly: 'We should be clear about the source of this violence [...] Russia is arming, leading, training, and fighting alongside anti-government forces' (in Peterson 2017). A year later, Harry Kaiman, Chargé d'Affairs with the US Mission to the OSCE, cautioned that peace prospects were hindered by Russia's arming, training, leading, and fighting alongside the separatists (2018).

Yet proxy is only one of many strategic relations shaping the dynamics of political violence captured by hybrid activity, despite acting as the 'incumbent' descriptor for the relationships between regular and irregular forces. By thinking just about 'proxies, research obfuscated the complexity of the strategic environment. For long, this has moved to a composite structure in which the fighting dyad is no longer just Side A vs Side B, but has seen multiple, strategic, operational, and tactical arrangements of either formal or informal character on both sides (Huber 2002). More importantly, it has pushed to the side important considerations about the nature of the distribution of the monopoly of violence among actors, and the emergence of security markets (Branović and Chojnacki 2011) where violence is simply managed by the state (Staniland 2012). As Carey and Mitchell recently put it, governments often 'settle for less than a monopoly of violence' $(2017,128)$, with proxies being one conduit of managing this situation. Recent scholarly efforts have refined our understanding of proxies (Berman and Lake 2019; Rauta 2018; Waldman 2018; Mumford 2013; Hughes 2012), delineated between proxy and auxiliary relationships (Rauta in Brown et al 2019, 2016; Scheipers 2015), and identified surrogacy as a standalone strategic relationship (Krieg and Rickli 2019; 2019; Waldman 2019; Krieg 2016; Hughes and Tripodi 2009). The complexity of the consumption and management of violence in contemporary settings, and the differences between proxies, auxiliaries, and surrogates are relevant to the hybrid warfare debate. These insights were facilitated by a shift in conflict research on the micro dynamics of political violence with a keen focus on the integrated study of militias and rebel groups (Jentzsch et al 2015, 755).

Research acknowledged that a wide range of non-state armed actors were being employed to act clandestinely for objectives that regular forces were unwilling or unable to achieve and as a rational means to govern and control (Davies 2009, 222; Schlichte 2009, 247). With a focus on paramilitaries, Ariel Ahram argued that states find multiple ways to accommodate the persistence of non-state actor (2011), and Carey et al. analysed how and why states may use militias as a way to delegate certain types of violence against civilians (2015; Cohen and Nordås 2015; Eck 2015; Forney 2015). Drawing on Carey et al.'s differentiation between informal and semi-official progovernmental militias (2013), Aliyev distinguished between 'state-manipulated' and 'state-parallel' militias (2016), and Paul Staniland determined that states have ideology-driven and 'often unexpected relationships with non-state armed groups' (2015a: 771). He explained that these actors 
can occupy an ally, enemy, or grey zone ideological space and, elsewhere categorised the role of militias in elections (2015b). Drawing on this debate, the article presents a taxonomy of strategic relationships between regular and irregular, official and unofficial actors segmenting the military domain of hybrid activity. Thinking typologically provides the advantage of simplicity by presenting a theoretically productive way of capturing phenomena diversity. It offers a trade-off which is not without analytical costs, and previous efforts to classify have been criticised for failing to account for factors with significant consequences, such as mode of operation (Clayton and Thomas 2016, 500).

The proposed classification is informed by two considerations - relational embeddedness and relational morphology - as described in Figure 1, and detailed in Figure 2. I present relational embeddedness as a way of capturing the degree to which the pursuit of coercive goals is done solely by/through the irregular or in cooperation with/alongside regular forces. The emphasis on the distinction between 'by/through' and 'in cooperation with/alongside' taps into the framing used to explain the emerging model of collaborative fighting involving local armed non-state actors, conceptualised by the US armed forces as the 'by, with, and through' (BTW) approach. As General Joseph L. Votel explains, the approach involved operations "led by [our] partner, state or nonstate, with enabling support from the Unites States or U.S.-led coalitions, and through U.S. authorities and partner agreements" (emphasis in original, Votel and Keravuori, 2018). The role, aims, and employment of non-state actors in the BTW approach speak to a different strategic context than hybrid warfare and their similarities and differences should be assessed separately. However, what is relevant to my conceptualisation of embeddedness is the logic of describing and pursuing relationships through functional identification. This has also been applied by Böhmelt and Clayton to distinguish between paramilitaries and pro-governmental militias (2016). Embeddedness, therefore, becomes a measure of the interactivity of the mode of operations employed towards reaching the desired strategic ends. It is not an indicator of the complexity of relationship nor of the control mechanisms underlying it (Bowen 2019). Simply put, embeddedness describes the structural relationship between regulars and irregulars, and the 'by/through', 'in cooperation with/alongside' pairing enables distinguishing between direct and indirect embeddedness, which form the first classificatory criterion.

\section{[INSERT FIGURES 1 and 2. HERE]}

The second criterion is that of relational morphology. In a recent article, Ahram complained that research on the varieties of relationships between state and non-state actors is 
hindered by the application of Principal-Agent theory and its logic of delegation. He called for future etiological mechanisms to move beyond this framework (2016). Relational morphology attempts this by distinguishing between supplementary and delegatory pathways of relationship constitution. Supplementary morphology identifies a relationship in which the non-state actor element provides a complementary, additive value through combination. This is in contrast to the delegatory one in which the irregular replaces the regular entirely through substitution. Together, relational embeddedness and relational morphology delineate four patterns of interactions 'proxy', 'auxiliary', 'surrogates', and 'affiliated' - which I discuss next in reference to the Ukrainian case in a theory-building effort. The case study presents sufficient variation to help delineate theoretically the proposed schema given the arrays of volunteers, mercenaries, gangs, criminals, self-defence forces and militias, and their multiple modes of interaction (Galeotti 2016, 285).

\section{Auxiliary Forces}

The annexation of the Crimean Peninsula by Russia followed the wave of violent protests, which started in Kiev in November 2013 and which led to the removal of Viktor Yanukovych's regime. The situation emerged against the backdrop of long-standing tensions in Ukraine over its relationship to both the European Union and the Russian Federation (Freedman 2014; Rauta and Mumford in Dover et al 2017). As discussed above, the operation was soon referred to as 'hybrid warfare', as it involved disinformation, political disruption and propaganda. Concerning the military dimension, the hybrid operations combined Russian Special Forces and local self-defence militias. The latter played 'largely an auxiliary role' (Galeotti 2016, 284-295; Rauta 2016), and as such represent the first type of regular-irregular relationship: auxiliary.

Auxiliaries have often been labelled as 'unlawful' and have received scholarly attention especially in the context of counterinsurgency (Rauta in Brown et al 2019, 2016; Scheipers, 2015). The expanded typology presented in Figure 1, allows us to define auxiliary forces as armed groups that are not part of the regular forces but that are directly embedded into the structure of fighting operating in collaboration with or alongside regulars. Their relationship to the regular takes a supplementary form with the groups providing additive value through combination. Combination underlines a pattern of strategic collaboration and association: non-sequential arrangement and rearrangement of militia activities in support of and with regular forces. Auxiliaries, therefore, act as force multipliers, in defensive or offensive roles, accompanying or being accompanied by regulars in operation. They identify a collusion pathway of working jointly towards coercive ends. As Scheipers argues, they 
are simply military forces that support the military efforts of regular armed forces of the state (2015).

In Crimea, the auxiliaries contributed to activities ranging from organising and participating in pro-Russian protests to roadblocking and other efforts designed to enforce the takeover of the peninsula. As events unravelled, for example, they blocked access to OSCE military observers and prevented pro-Kiev manifestations. The mobilisation of auxiliaries was carried out by groups such as the Night Wolves, the famous biker gang locally lead by Dmitry Sinichkin (Salem 2014) and involved Afghan War veterans, with Frantz Klintsevich playing an important role. Reports by the OSCE added Cossacks to the mix (Walker 2014), and self-defence militias expanded across the peninsula. The disbandment of the ruthless Berkut police force by the new authorities in Kiev provided much-needed manpower and expertise to these militias. Adding to this, was Crimea's long history of criminality, turf wars, and gangs. The powerful criminal undertones of the auxiliaries should not distract from their role as military auxiliaries. As Galeotti explains in a new study of the relationship between organised crime and Russian politics, in Crimea, 'the criminals were combatants, not just collaborators' (2018b, 243). Interviews with militia leaders capture this very aspect, as well as their operation alongside and under regular forces command. One such leader, Vladimir Melnik, described his militia as peaceful yet 'military people' following received orders (Salem and Walker 2014). As such, the category of auxiliary draws on the battlefield collaboration between irregular and regular and feeds into a long conversation on their strategic utility (Andres et al 2005/2006; Rauta in Brown et al 2019). It also adds more specificity to comparisons with 'compound warfare' understood as the intentional and simultaneous use of regular main force with dispersed irregular forces (Huber 2002). 'Auxiliary' moves beyond the point of synergy to capture a wider remit of kinetic purposes (Rauta 2016), whose battlefield impact is the result of strategic combination and coordination.

\section{Proxy Forces}

As mentioned above, the category of 'proxy' is the one the literature has referenced and explored the most. To explain the role of proxies in the context of the Ukrainian crisis, we have to shift away from Crimea and onto the violence in the South-East of Ukraine. From the very start of the crisis, the intended strategic outcome for the region desired by Russia was different to that for Crimea. If Crimea was to be part of the Russian Federation, the South-East was to be transformed into a frozen conflict much like the one in Transnistria. This translated in the role and relationship to non-state actors as well: their role was not just military as it was with the 
auxiliaries, but also politico-strategic (Rauta 2016). As opposed to a covert direct military intervention, Russia waged an indirect, proxy war. The latter has been defined as 'the polarisation of competing political goals between two organised parties, a Beneficiary and a Target, in which at least one party engages the other indirectly in sustained collective violence through a third party, the Proxy' (Rauta 2018, 457).

Following this definition, I conceptualise proxy forces as armed groups that are not part of regular forces but that fight for and on behalf of states wishing to alter the strategic outcome of a conflict while remaining external to it. The proxy is indirectly embedded with the external state in as much as it becomes their conduit of armed violence on the basis of state's provision of a range of support. As such, they are not part of the regular forces and they operate by entirely replacing the regular forces on the battlefield. Looking at Figure 1, the specificity of the proxy category is determined by the armed groups becoming the forces through which the regulars fight, in a strategic relationship resulting from the regulars' delegation of war to the irregulars (Salehyan 2010). This relationship is by no means linear and unidirectional, it can diverge (Brown 2016, 247). Salehyan et al (2011) presented this as a joint venture in which the external state must be willing to offer support and the group must be willing to accept it. More recently, San-Akca presented selection mechanisms between the parties (2016), and Rauta developed a goal-preference explanation (2018, 457).

The self-defence militias in the South East emerged from weak political projects such as the Ukrainian Front (Wilson, 2014). With Russian backing they transformed in separatist rebels fighting for various degrees of autonomy, independence, and unification with Russia. Their warfighting took, or tried to take, a distinctly conventional style but their opportunism and lack of training and experience led to minor successes (Savage 2018). The referendums of independence in Luhansk and Donbas produced two unrecognised people's republics, and the advance of the Ukrainian forces required Russian direct involvement which took place in August 2014 when the Kremlin sent in approximatively 4000 regular troops (Savage 2018, 83). The proxy gamble failed for Russia as it presumed it could fight an undeclared war cheaply with local militias, and it created 'a situation in which it was often scarcely in control of its notional proxies' (Galeotti 2018b, 247). As Savage $(2018,84)$ described, proxies were purged and reduced to 'a buffer and a screening force', following Russia’s political directives in the Minks discussions aimed at ending the violence.

Affiliated Forces 
As Figure 1 shows, the category of 'affiliated forces' tries to identify a strategic relationship based, much like in the case of proxies, on delegation of violence by regulars external to the conflict whose outcome they seek to alter. In contrast to proxies, however, affiliated forces are directly embedded, working 'in collaboration/alongside' regulars, often in murky arrangements which challenge easy attribution of action in the battlefield. I define affiliated forces as armed groups that are unofficially part of the regular forces, and that fight for and on behalf of states wishing to alter the strategic outcome of a conflict while remaining external to it. Affiliated forces have a symbiotic, formal, yet legally dubious relationship with the state acting as an invisible arm.

Affiliated forces capture the rise of violent non-state actors for whom the battlefield presents opportunities of profit-maximisation and revenue accumulation. This is specifically the case for mercenaries and shadowy private military and security contractors. Sean McFate's recent study on the modern mercenary distinguishes between mercenaries and military enterprisers. The latter were defined as 'private business entities that deliver to consumers a wide spectrum of military and security services, once generally assumed to be exclusively inside the public context' (Singer 2003, 8). The former, however, are private armies that can 'conduct autonomous military campaigns, offensive operations, and force projection' (McFate 2017, 14).

The contracting of warfare was evident during the violence in the south east of Ukraine and captured what Deborah Avant called external force projection (2005). The commodification of armed conflict in Russia has a long history (Sukhankin 2019), and is intertwined with the Russian programme of modernisation of its armed forces. More importantly, as Christopher Spearin argued, the 'relationship [...] is quite intimate' $(2018,42)$, functioning technically as an arm of the state. From the point of view of the typology's relational embeddedness, this comes under its direct category. Sukhankin argues that they are on an equal footing with the regulars, yet kept separate through their de facto illegal status (2019). Marten observed recently that the groups are used in conjunction with Russian military forces (2019). This is why as a distinct category, affiliated forces manage to work, rather oxymoronically, in collaboration with regulars external to the conflict. For this reason, the proposed schema presents affiliated forces as strategically subordinated to the external state and its regular forces, assuming roles and responsibilities that offer it deniability and shield regulars from backlash. The veil of deniability functions, however, like an open secret and there have been disagreements resulting from the unrecognised subordination of such non-state actors. Evgeny Shabayev, the leader of a paramilitary organisation known as the Khovrino Cossack Society, active in Ukraine, has called for social benefits and better legal protections for Russia's private military contractors (Ilyusgina et al 2018). 
Yet, most mercenary activities in Ukraine coalesce around the Wagner Group, a shadowy mercenary group now thought to be active in Syria, Sudan, Libya, and the Central African Republic (Brown 2018). The mercenary group boats the features of the proposed category. Peter MacKay, the former Canadian Defence Minister, holds the group responsible for extraterritorial work on behalf of Russia without Kremlin attribution (in Giglio 2019). Similarly, former U.K. Defence Secretary Gavin Williamson spoke of the Wagner Group as allowing 'the Kremlin to get away with murder while denying blood on their hands' (in Shuster 2019). The range of activities was wide. The first Wagner soldiers who appeared in Ukraine were specialists who worked under the direction of handlers in the Russian defence ministry, according to the country's domestic intelligence agency, the Security Service of Ukraine. The fighting was done by a mix of locally recruited and foreign fighters, with the Wagner Group boosting an all-Serbian platoon. In July 2018, Ukraine presented to the International Court of Justice a list of foreign fighters linked to the Wagner Group that were actively engaged in the Donbas region (UAWIRE, 2018). Wagner was also employed to train and aide proxy rebels while also acting as an enforcer of control (Giglio 2019), assassinating rebel leaders such as Alexander Bednov, the LPR's so-called Minister of Defence, or Aleksey Mozgovoy, the leader of the Prizrak Brigade (Sukhankin 2018). Deploying Wagner as a mechanism of proxy control underscores the relevance of different types of relationships between regular and irregular forces in the battlespace. The Ukrainian Security Service (SBU) linked the use of private violence to 'hybrid warfare', identifying the Wager group as an instrument of 'Russia's hybrid aggression against the rest of the world'. In parallel to this, Assistant to President Putin, Vladislav Surkov, was responsible for the creation of a mercenary group called the Union of Donbass Volunteers (Sukhankin 2019). The group is directly linked to the Russian authorities and became a tool for managing volunteers in the Donbass region. Their fighting involved working with groups such as the Union of Russian Troopers, Union of Afghan Veterans, and Cossack organisations, whilst cooperating with a pro-Russian organisation abroad: the Union of Serbian Veterans and Volunteers; 63rd Brigade; or National Union of Volunteers (Lisunov et al. 2017). By presenting the category of 'affiliated forces', the schema captures the commerce-warfighting linkages of the military domain of 'hybrid warfare'. The links between affiliated forces and proxy forces point to the need to expand our theoretical thinking about the variety of actors and their role in fighting in the hybrid battlespace.

\section{Surrogate Forces}


The last category is that of 'surrogate forces'. With it, the schema integrates a new turn in the study of third parties in warfare, namely the rise of 'surrogate warfare'. One of the earliest academic observations drew a distinction between surrogates, auxiliaries, and proxies. The latter included third parties 'employed by a state in any external conflict where the employment of its own forces may be deemed undesirable' (Hughes and Tripodi 2009, 3). Auxiliaries referred to forces working alongside regulars in inter-state warfare (Hughes and Tripodi 2009, 3). Surrogates, on the other hand, were pro-governmental groups or militias 'utilised in an internal war between a government and armed opposition' and that were 'aligned with the government but not formally part of it' (Hughes and Tripodi 2009, 4/5).

More recently, Andreas Krieg expanded the definition of surrogacy by linking it to the externalisation of the burden of war to 'human and technological surrogates' (2016, 97). In their recent monograph, Krieg and Rickli argue that 'the uniqueness of surrogate warfare lies not so much in the departure from conventional trinitarian means of warfare but in its nature as nontrinitarian socio-political phenomenon' (2019). Drawing on this, the schema proposes its final category of 'surrogate forces' as armed groups through which regular forces of the state involved in the ongoing conflict fights (either by being partially supplemented or wholly replaced). Surrogates are indirectly embedded in light of their operational-tactical interaction with the regulars: taking over the burden of fighting as a response to the inability of the state to assert the monopoly of violence. This should not be confused with the legal developments through which paramilitaries are slowly integrated into the regular force. As Malyarenko and Galbreath observed, initially, the Ukrainian government supported the paramilitary battalions informally, retaining formal distance (2016).

Surrogates are different to the other aforementioned categories because they observe a relationship not with external states wishing to change the outcome of the conflict, but with the very state whose authority is contested through violence. Faced with a chronically underfunded military that had for a long time been neglected and subjected to the country's rampant corruption, the Ukrainian defence establishment found itself unable to present even the slightest response to the Russian aggression in Crimea and the ensuing separatist violence in Ukraine. The answer was volunteer paramilitaries. Very early on, the Ukrainian Ministry of Defence issued official decrees to create paramilitary formations to supplement the Army and the National Guard. What was unique was that funding for such groups was almost entirely private. It was crowdfunded through the Volunteer Council, a civil group within the Ministry of Defence (Weiss 2015). Paramilitary groups and self-defence militias grew quickly. The Ukrainian Volunteer Army, the Aidar battalion, the Azov and Donbas battalions, Right Sector, Dnipro-1, and the Organisation of Ukrainian Nationals are some of the most famous. Recent research points to there being around 40 to 50 of 
such groups (Aliyev 2016). Their military performance was mixed and their connection to Nazi ideology raised more problems than providing solutions. The fact that some of these groups were absorbed in the official structures of the armed forces emphasises the dependence of the regular forces on these groups, through which significant fighting was carried out. This was the case of the Azov and Donbas battalions which were legally incorporated into the National Guard (Aliyev 2016, 509). The Right Sector was included in the Ministry of Defence. Surrogates present a final window into understanding the complexity of the kinetic battlefield in hybrid warfare. We need to talk about these not merely as combatants engaging enemy formation, but also as engaging morphologically similar actors. Insubordination, private agendas, and paramilitary rivalries and feuds all divert and add layers of violence which shape the battlefield. By trying to distinguish their role and interactions surrogate forces occupy an important space in the spectrum presented here next to proxy, auxiliary, and affiliated forces.

\section{Conclusion}

The article presented a typology of non-state actors in hybrid warfare by taking into account their relationships with regular state forces, external or internal to the conflict. In doing so, it devoted special attention to the kinetic domain of hybrid warfare following a recent trend towards disaggregating the many layers of hybrid activity. Understanding these regular-irregular relationships as involving proxy, auxiliary, surrogate, and affiliated forces adds greater specificity to a problem which, in spite being central to a vociferous debate, has escaped so far classificatory and theoretical efforts. The four categories act as custodians of ideal types which attempt to make sense of complex, and often murky, strategic environments. As Carey and Mitchell pointed out recently, 'exhaustive, exclusive, and meaningful categories are hard to find', and categorising 'is empirically as well as normatively contested terrain' $(2017,130)$. The same holds for the theoretical efforts of this paper. David Sterman recently quoted Norman Roule, a CIA veteran and former National Intelligence Manager for Iran at the Office of the Director of National Intelligence, who argued that 'one of the difficult words that is often thrown around is proxy. If you want to have analysts or think tanks work themselves into a frazzle, ask them the definition-the difference between proxy, surrogate, and partner-and come back four days later and see who's still moving on the floor' (2019). Nevertheless, the ideal types presented here serve to point to the multiple dynamics of violence. They attempt to contribute to this empirical maze of variations of regularirregular relationships which so far have been reduced to just proxyship. As Scheipers put it, the task of experts is to present policymakers with the vocabulary necessary to have an informed 
debate (2015). The taxonomical effort developed here yields significant returns, which are able to inform both the academic and policy debate on the future developments of hybrid warfare.

First, a clearer grasp on the actor relationships and their shaping of the conflict space cumulatively brings together four current directions of inquiry into contemporary war and warfare. The literatures on proxies, auxiliaries, and surrogates address key questions by interrogating variation in the delegation of war to non-state actors, which the emergent hybrid war literature captures as empirical puzzles. Given the propensity of the concept of 'hybrid warfare' to diffuse across issues ranging from intelligence and propaganda to cyber war, a cumulative perspective helps knowledge progress successfully. Having embedded the typology in the wider literature on paramilitaries and pro-governmental militias demonstrates that the hybrid debate should not be divorced from the wider study of political violence.

Second, an actor-centred classification is a welcomed effort in light of myriad of actors involved in hybrid warfare. Recently, Julie Fedor introduced the category of 'active celebrity combatant' and explored the case of Zakhar Prilepin as a conduit for 'the normalisation of war and violence more broadly in Russian popular culture and public life' (2019, 19). Similarly, Mark Galeotti spoke of the Kremlin's latest hybrid warfare assets, namely gangs, thugs, and gangsters (2018b). These add to other dimensions such as the political mobilisation of the Russian oligarchy as a tool in hybrid war and the recent 'weaponization' of the Russian Orthodox Church as a conduit and lobby for Russian greatness. As the American debate moves increasingly towards discussing grey zone as opposed to the hybrid concept, ${ }^{4}$ and Galeotti invites scholars and practitioners to move beyond the hybrid debate (2019). This article anchored a problem which is as important as the cyber, informational, or socio-economic dimensions of hybrid activity. In fact, the article's limitations result from not drawing links to these other dimensions, which is something future research should do and, more importantly, outside of the Ukrainian context.

From this point of view, the article invites future research to address not just pending questions but think creatively in terms of puzzles. The article identified different types of actors with different roles in warfare by focusing on the strategic relationship they enter into with regular state forces. One potential puzzle drawn from here is to think about why some of these externally supported rebels decided to fight conventionally, and not irregularly. Hew Strachan noted early on in the hybrid debate that hybrid war is already being used to embrace not only a war in which regular and irregular actors take part, but also hybrid actors in a war who might opt to fight a regular war rather than an irregular one' $(2009,22)$. Several of the Russian supported forces

\footnotetext{
${ }^{4}$ I am thankful to the reviewers for drawing my attention to the epistemological shifts and differences between the American debate, on one hand, and the British-European, on the other.
} 
fashioned and attempted to fight in clearly conventional ways, yet some did not. Added to this are questions of performance, and whether external support professionalises these self-militias and, if so, at what cost. The many puzzles surrounding hybrid war/warfare point to there being significant gaps in our knowledge, but also, more positively, ample avenues of research.

Figure 1. Matrix of Typology

\section{Relational Morphology}

Supplementary Delegatory

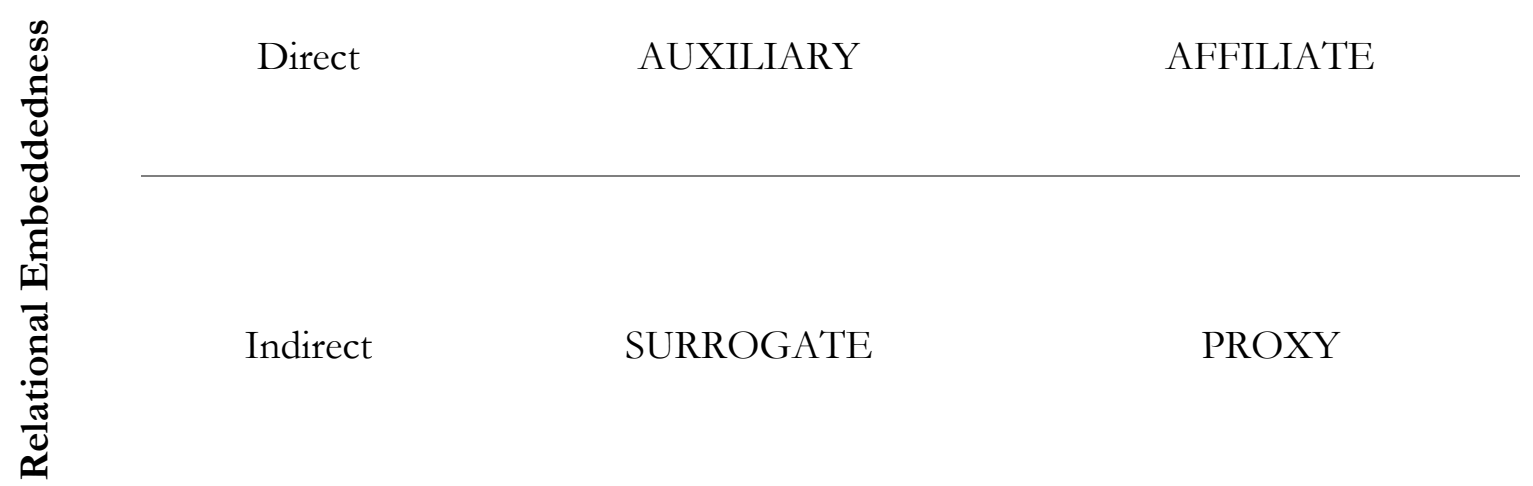


Figure 1. Matrix of Typology - Expanded

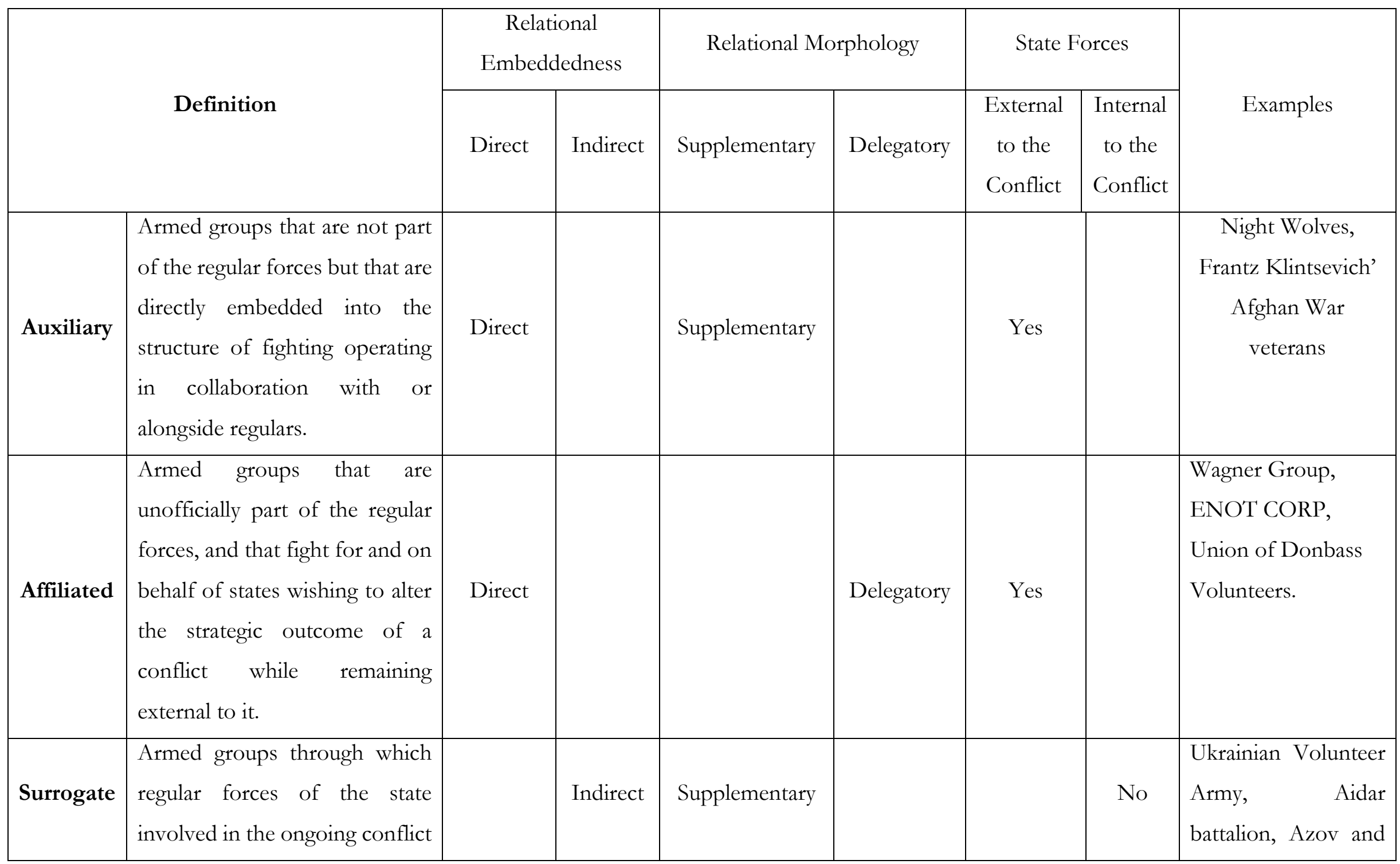




\begin{tabular}{|c|l|l|l|l|l|l|}
\hline \multirow{2}{*}{ Proxy } & $\begin{array}{l}\text { fights (either by being partially } \\
\text { supplemented or wholly } \\
\text { replaced). }\end{array}$ & $\begin{array}{l}\text { Armed groups that are not part } \\
\text { of regular forces but that fight } \\
\text { for and on behalf of states } \\
\text { wishing to alter the strategic } \\
\text { outcome of a conflict while } \\
\text { remaining external to it. }\end{array}$
\end{tabular}


Bibliography

Ahram, Ariel I. (2011) Proxy Warriors. The Rise and Fall of State-Sponsored Militias (Stanford, Stanford University Press).

Ahram, Ariel I. (2016) 'Pro-Government Militias and the Repertoires of Illicit State Violence', Studies in Conflict \& Terrorism 39(3), 207-226.

Aliyev, Huseyn (2016) 'Strong militias, weak states and armed violence: Towards a theory of 'stateparallel' paramilitaries', Security Dialogue, 47(6), 498-516.

Almäng, Jan (2019) 'War, vagueness and hybrid war', Defence Studies, Online First.

Avant, Deborah (2005) The market for force: The consequences of privatizing security (Cambridge: Cambridge University Press).

Andres, Richard, Craig Wills, and Thomas Griffith (2005-2006) 'Winning with allies: The strategic value of the Afghan model', International Security, 30(3), 124-160.

Barkawi, Tarak (2016) 'Decolonising war', European Journal of International Security, 1(2), 199-214.

Bartles, Charles K. (2016) 'Getting Gerasimov Right’, Military Review, January-February, 30-38.

Batyuk, Vladimir I. (2017) 'The US concept and practice of hybrid warfare', Strategic Analysis, 41(5), 464-477.

Bentzen, Naja (2018) 'Russia-Ukraine conflict flares up in the Azov Sea', European Parliamentary Research Service.

Berman, Elia and David A. Lake (Eds.) (2019) Proxy Wars: Suppressing Violence through Local Agents (Cornell University Press)

Bowen, Andrew S. (2019) 'Coercive diplomacy and the Donbas: Explaining Russian strategy in Eastern Ukraine', Journal of Strategic Studies, 42(3-4), 312-343.

Böhmelt, Tobias and Govinda Clayton (2016) 'Auxiliary Force Structure: Paramilitary Forces and Pro-Government Militias', Comparative Political Studies, 51(2), 197 - 237.

Branović, Željko and Sven Chojnacki (2011) 'The logic of security markets: Security governance in failed states', Security Dialogue, 42(6)

Brown, Daniel (2018) ‘3 countries where Russia’s shadowy Wagner Group mercenaries are known to operate', Business Insider, 27 April.

Brown, Seyom (2016), 'Purposes and pitfalls of war by proxy: A systemic analysis', Small $W$ ars \& Insurgencies, 27(2), 243-257.

Caliskan, Murat (2019) 'Hybrid warfare through the lens of strategic theory', Defense \& Security Analysis, Online first. 
Carey, Sabine C. and Neil J. Mitchell (2017) 'Progovernment Militias', Annual Review of Political Science, 20, 127-147.

Carey, Sabine C., Neil J. Mitchell, and Will Lowe (2013) 'States, the security sector, and the monopoly of violence: A new database on pro-government militias', Journal of Peace Research, 50(2), $249-245$.

Carey, Sabine C., Michael P. Colarsi, and Neil J. Mitchell (2015), 'Government, informal links to militias, and accountability', Journal of Conflict Resolution, 59(5), 850-876.

Charap, Samuel (2015) 'The ghosts of hybrid war', Survival, 57(6), 51-58.

Clayton, Govinda and Andrew Thomson (2016) 'Civilianizing Civil Conflict: Civilian Defense, Militias and the Logic of Violence in Intra-State Conflict', International Studies Quarterly, 60(3), 499510.

Cohen, Dara Jay and Ragnhild Nordås (2015) 'Do states delegate shameful violence to militias? Patterns of sexual violence in recent armed conflicts', Journal of Conflict Resolution, 59(5), 877-898.

Cormac, Rory and Richard J. Aldrich (2018) 'Grey is the new black: Covert action and implausible deniability', International Affairs, 94(3), 477-494.

Cooper, Helene (2016) 'Wars of the future? Picture big armies and many fronts', The New York Times, 11 June.

Cooper, Helene (2018) 'Cold War takes new meaning for U.S. marines at a NATO exercise', The New York Times, 31 October.

Davis, Diane E. (2009) 'Non-State armed actors, new imagined communities, and shifting patterns of sovereignty and insecurity in the modern world', Contemporary Security Policy, 30(2), 221-245.

Eck, Kristine (2015) 'Repression by proxy: how military purges and insurgency impact the delegation of coercion', Journal of Conflict Resolution, 59(5), 924-946.

Fedor, Julie (2018) 'Spinning Russia’s 21 ${ }^{\text {st }}$ century wars', The RUSI Journal, 163(6), 18-27.

Forney, Jonathan Filip (2015) 'Who can we trust with a gun? Information networks and adverse selection in militia recruitment', Journal of Conflict Resolution, 59(5), 824-849.

Freedman, Lawrence (2017) The future of war. A history (London: Allen Lane).

Fridman, Offer (2017) 'Hybrid warfare or gibridnaya voyna?', The RUSI Journal, 162(1), 42-49.

Fridman, Offer (2018) Russian Hybrid Warfare': Resurgence and Politicization (Oxford: Oxford University Press).

Galeotti, Mark (2016) 'Hybrid, ambiguous, and non-linear? How new is Russia's new way of war?', Small Wars \& Insurgencies, 27:2, 281-301.

Galeotti, Mark (2018a) '(Mis)Understanding Russia’s two hybrid wars', Euroæine, 29 November.

Galeotti, Mark (2018b) The Vory. Russia's super Mafia (Yale: Yale University Press). 
Galeotti, Mark (2019) Russian Political War: Moving Beyond the Hybrid (London: Routledge).

Gates, Robert M. (2009) 'A balanced strategy: Reprogramming the Pentagon for a New Age', Foreign Affairs, January-February.

George, Alexander and Andrew Bennett (2005) Case Studies and Theory Development in the Social Sciences (Cambridge, MA: MIT Press).

Gerring, John (2004), 'What is a Case Study and What is it Good for?', American Journal of Political Science, 98(2), 341-354.

Gerasimov, Valery (2013) 'The value of science in prediction', Military-Industrial Kurier, February 27 , trans. Robert Coalson.

Giglio, Mike (2019) 'Inside The Shadow War Fought By Russian Mercenaries', BuzzFeedNews 17/04/2019. Available at: https://www.buzzfeednews.com/article/mikegiglio/inside-wagnermercenaries-russia-ukraine-syria-prighozhin

Glenn, Russell W. (2009) 'Thoughts on hybrid conflict', Small Wars Journal.

Gray, Colin S. (2008-2009) 'The $21^{\text {st }}$ century security environment and the future of war', Parameters, 38(4), 14- 26.

Hall, Jonathan (2018) 'Hybrid war in the Sea of Azov', Wavell Room, 29 December.

Hoffman, Frank G. (2007) 'Conflict in the $21^{\text {st }}$ century: the rise of hybrid wars', Potomac Institute for Policy Studies.

Hoffman, Frank G. (2009a) 'Hybrid vs Compound War', Armed Forces Journal, October.

Hoffman, Frank G. (2009b) 'Hybrid warfare and challenges', Joint Forces Quarterly, 52(1), 34-39.

Hoffman, Frank G. (2014) 'On not-so-new-warfare: Political warfare vs hybrid threats', War on the Rocks, 28 July.

Huber, Thomas (2002) Compound warfare. That fatal knot (Fort Leavenworth, Kansas: U.S. Army Command and General Staff College Press).

Hughes, Geraint and Christian Tripodi (2009) 'Anatomy of a surrogate: historical precedents and implications for contemporary counter-insurgency and counter-terrorism', Small Wars \& Insurgencies, 20(1), 1-35.

Hughes, Geraint (2012) My enemy's enemy: proxy warfare in international politics (Eastbourne: Sussex Academic Press).

Ilyushina, Mary, Nathan Hodge, and Sebastian Shukla (2018) 'Russian vets seek to bring the Kremlin's mercenaries in from the cold', CNN, 19 November.

Jacobs, Andreas and Guillaume Lasconjarias (2015) 'NATO's hybrid flanks. Handling unconventional warfare in the South and the East', NATO Research Paper, No 11. 
Jensen, Benjamin, Brandon Valeriano and Ryan Maness (2019) 'Fancy bears and digital trolls: Cyber strategy with a Russian twist', Journal of Strategic Studies, Online First.

Jentzsch, Corinna, Stathis N. Kalyvas, and Livia Isabella Schubinger (2015), 'Militias in Civil Wars', Journal of Conflict of Resolution, 59(5), 755-769.

Johnson, Robert (2018) 'Hybrid war and its countermeasures: A critique of the literature', Small Wars \& Insurgencies, 29(1), 141-163.

Jones, Seth (2018) 'The future of war is irregular', The National Interest, 26 August.

Kaiman, Harry (2018) 'Response to the annual report by the Director of the OSCE Conflict Prevention Centre, Ambassador Marcel Peško', US Mission to the OSCE, 08 November.

Kragh, Martin and Sebastian Åsberg (2017) 'Russia's strategy for influence through public diplomacy and active measures: the Swedish case', Journal of Strategic Studies, Online First.

Krieg, Andreas (2016) 'Externalizing the burden of war: the Obama Doctrine and US foreign policy in the Middle East', International Affairs, 92(1), 97-113.

Krieg, Andreas and Jean-Marc Rickli (2019) 'Surrogate warfare: the art of war in the 21 st century?', Defence Studies, 18(2), 113-130.

Krieg, Andreas and Jean-Marc Rickli (2019) Surrogate warfare. The transformation of war in the twentyfirst century (Georgetown: Georgetown University Press).

Lanoszka, Alexander (2016) 'Russian hybrid warfare and extended deterrence in eastern Europe', International Affairs, 92(1), 175-195.

Lanoszka, Alexander (2019) 'Disinformation in international politics', European Journal of International Security, Online First.

Lisunov, Dmytro, Oleh Baturin, and Serhiy Petrenko (2017) Why Surkov Needs Private Army: Union of Donbas Volunteers (UDV) as Reserve of National Guard of Russia, InformNapalm, 30/04/2017 Available at: https://informnapalm.org/en/surkov-needs-private-army-uniondonbas-volunteers-reserve-russian-guard/

Macfarquhar, Neil (2018) 'Wider fight threatened after clash off Crimea', The New York Times, 28 November.

Mattis, James N. and Frank Hoffman (2005) 'Future warfare: The rise of hybrid wars', Proceedings Magazine, 132(11), 233-235.

Malyarenko Tetyana and David J. Galbreath (2016) 'Paramilitary motivation in Ukraine: beyond integration and abolition', Southeast European and Black Sea Studies, 16:1, 113-138.

Marten, Kimberly (2019), 'Russia's use of semi-state security forces: the case of the Wagner Group', Post-Soviet Affairs, 35(3), 181-204. 
Mälksoo, Maria (2018) 'Countering hybrid warfare as ontological security management: the emerging practices of the EU and NATO', European Security, 27(3), 374-392.

McFate, Sean (2017) The modern mercenary (Oxford: Oxford University Press).

Monaghan, Andrew (2016) 'Putin's way of war. The 'war' in Russia's hybrid warfare', Parameters, 45(4), 65-74.

Mumford, Andrew (2013) Proxy Warfare (Cambridge: Polity Press).

Oren, Elizabeth (2016) 'A dilemma of principles: The challenges of hybrid warfare from a NATO perspective', Special Operations Journal, 2(1), 58-69.

Peterson, Nolan (2017) 'Why the was in Ukraine matters to America', Daily Signal, 15 December. Pettersson, Therése and Kristine Eck (2018) 'Organized violence, 1989-2017', Journal of Peace Research, 55(4), 535-547.

Rauta, Vladimir (2016) 'Proxy agents, auxiliary forces, and sovereign defection: assessing the outcomes of using non-state actors in civil conflicts', Southeast European and Black. Sea Studies, 16(1), $91-111$.

Rauta, Vladimir and Andrew Mumford, (2017) 'Proxy wars and the contemporary security environment', in Robert Dover et al (Eds.) The Palgrave Handbook of Security, Risk and Intelligence (London: Palgrave Macmillan, 2017), 99-116.

Rauta, Vladimir (2018) 'A structural-relations analysis of party dynamics in proxy wars', International Relations, 32(4), 449-467.

Rauta, Vladimir (2019) 'Conceptualising the regular-irregular engagement: the strategic value of proxies and auxiliaries in wars amongst the people', in David Brown et al. (Eds), War Amongst the People, (Havant: Howgate Publishing Limited).

Ratsiborynska, Vira (2018) 'Russia's hybrid warfare in the form of its energy manoeuvres against Europe: how the EU and NATO can respond together?', NATO Research Paper, 147.

Renz, Bettina (2016) 'Russia and hybrid warfare', Contemporary Politics, 22(3), 283-300.

Renz, Bettina and Hannah Smith (Eds.) (2016a) 'Russia and hybrid warfare - going beyond the label', Prime Minister's Office, Finland, Aleksanteri Papers, No. 1.

Renz, Bettina and Hannah Smith (Eds.) (2016b) 'After hybrid warfare, what next? Understanding and responding to contemporary Russia', Prime Minister's Office/Finland, Publications of the Government's analysis, assessment and research activities, Vol. 44/2016.

Robinson Linda et al (2018) Modern political warfare. Current practises and possible responses (Santa Monica, CA: RAND).

San-Akca, Belgin (2016), States in disguise: causes of state support for rebel groups, (Oxford: Oxford University Press). 
Salehyan, Idean (2010) 'The delegation of war to rebels', Journal of Conflict Resolution, 54(3), 493-515. Salehyan, Idean, Kristian Skrede Gleditsch, and David E. Cunningham (2011) 'Explaining external support for insurgent groups', International Organization, 65(4), 709-744.

Salem, Harriet (2014) 'Ukraine: Night Wolves and unidentified military men seize key Crimea sites', The Guardian, 28 February.

Salem, Harriet and Shaun Walkerv (2014) 'Kiev announces plans to withdraw Ukrainian troops from Crimea', The Guardian, 19 March.

Savage, Patrick J. (2018) 'The conventionality of Russia's unconventional warfare', Parameters, 48(2), 77-85.

Scheipers, Sibylle (2015) 'Auxiliaries at war in the Middle East', Survival, 57:4, 121-138.

Schlichte, Klaus (2009) 'With the state against the state? The formation of armed groups', Contemporary Security Policy, 30(2), 246-264.

Schroefl, Josef and Stuart J. Kaufman (2014) 'Hybrid actors, tactical variety: rethinking asymmetric and hybrid war', Studies in Conflict \& Terrorism, 37(10), 862-880.

Seely, Robert (2017) 'Defining contemporary Russian warfare. Beyond the hybrid headline', The RUSI Journal, 162(1), 50-59.

Sengupta, Kim (2018) 'Two months ago, a Ukrainian military officer told me he saw an 'incident' with Russia coming - he didn't think it would be this soon', The Independent, 27 November.

Shushter, Simon (2019) 'How Putin Built a Ragtag Empire of Tyrants and Failing', Time Magazine, 04/04/2019.

Singer, P. W. (2003) Corporate Warriors (Cornell University Press).

Spearin, Christopher R. (2018) 'Russia's military and security privatization', Parameters, 48(2), 3949.

Staniland, Paul (2012) 'States, Insurgents, and Wartime Political Orders', Perspectives on Politics, 10(2), 243-264.

Staniland, Paul (2015a) ‘Armed groups and militaries elections', International Studies Quarterly, 59(4), 694-705.

Staniland, Paul (2015b) 'Militias, ideology, and the state', Journal of Conflict Resolution, 59(5), 770-793.

Sterman, David (2019) How Do We Move Beyond 'Proxy' Paralysis?, New America.

Strachan, Hew (2009) 'One war, joint warfare', The RUSI Journal, 154(4), 20-24.

Strachan, Hew and Sibylle Scheipers (2013) The Changing Character of War (Oxford: Oxford University Press). 
Sukhankin, Sergey (2019) War, Business and Ideology: How Russian Private Military Contractors Pursue Moscow's Interests. Available at: https://jamestown.org/program/war-business-andideology-how-russian-private-military-contractors-pursue-moscows-interests/

Sukhankin, Sergey (2018) 'Continuing War by Other Means': The Case of Wagner, Russia's Premier Private Military Company in the Middle East. Available at: https://jamestown.org/program/continuing-war-by-other-means-the-case-of-wagner-russiaspremier-private-military-company-in-the-middle-east/

Thomas, Timothy (2016) 'The evolution of Russian military thought: Integrating hybrid, newgeneration, and new-type thinking, The Journal of Slavic Military Studies, 29(4), 554-575.

Thornton, Rod (2015) 'The changing nature of modern warfare. Responding to Russian information warfare', The RUSI Journal, 160(4), 40-48.

UAWIRE (2018) 'Ukraine submits lists of foreign mercenaries who fought in the Donbas to the International Court of Justice', 04 July.

UNIAN (2018) 'Ukraine names pro-Russian Wagner mercenaries from Moldova, 10 October.

Van Puyvelde, Damien (2015) 'Hybrid war: Does it even exist?’, NATO Review Magazine.

Votel, Joseph L. and Eero R. Keravuori (2018) 'The By-with-Through Operational Approach', Joint Force Quarterly, 89(2), 48-55.

Waldman, Thomas (2018) 'Vicarious warfare: The counterproductive consequences of modern American military practice', Contemporary Security Policy, 39(2), 181-205.

Waldman, Thomas (2019) 'Strategic Narratives and US Surrogate Warfare', Survival: Global Politics and Strategy, 61(1), 161-178.

Walker, Peter (2014) 'Ukraine crisis: Putin spokesman downplays talk of new cold war', The Guardian, 07 March.

Walter, Barbara F. (2018) 'The new new civil wars', Annual Review of Political Science, 20, 469-486.

Weiss, Michael (2015) 'Crowdfunding the war in Ukraine - from Manhattan', Foreign Policy, 04 February.

White House (2017) National Security Strategy of the United States.

Wigell, Mikael (2019) 'Hybrid interference as a wedge strategy: a theory of external interference in liberal democracy', International Affairs, 95(2), 255-275.

Wilson, Andrew (2014) 'Ukraine conflict: the regime will finish what it started', The Guardian, 19 February. 
